\title{
An Analysis of Deixis in The 12 Angry Men Drama Script by Reginald Rose
}

\author{
Puji Ayu Lestari ${ }^{1 *}$, Iksora ${ }^{2}$ and Syanuwalini Syafruddin ${ }^{3}$ \\ ${ }^{1,2,3}$ Department of English Language Studies, Universitas Hasanuddin, Makassar, Indonesia \\ *lestaripa21f@unhas.ac.id
}

\begin{abstract}
One of the biggest problems in communication that could happen to the speaker and hearer is when both parties experience miscommunication about the meaning of the words that are related to the context of the situation. This study focused on deixis in "The 12 Angry Men" drama by Reginald Rose, because the plot of the story occurs in daily life, and drama script is one of the appropriate objects for analyzing dexis because the sentences in the drama script belong to spoken language. The data of this research were taken from Reginald Rose's drama script which were taken from her drama "The 12 Angry Men" included 12 juror's conversation. The result of this paper is the types of deixis found in the drama script of The 12 Angry Men by Reginald Rose are Personal Deixis, Temporal Deixis, Spatial Deixis and Social Deixis. The function of each deixis found in the drama script of The 12 Angry Men by Reginald Rose are personal deixis which refers to role of participant and addressee in the drama, Temporal deixis gives the information about the moment of the utterance in a context that is happened, Spatial deixis is to know the distance about the speech situation between the participants happened, and the last is social deixis to show the social status of the person included relational social or absolute social deixis
\end{abstract}

Key words: Deixis, drama, The 12 Angry Man.

\section{Introduction}

\section{Background}

Language is very important in human's life. People are able to convey their thoughts by using language. As communication, language is used to send messages from one to another. Language is defined as "the systematic conventional use of sound, sign, or written symbol in human society for communication and self expression."

Although language is the main tool of communication, the utterances that the speaker delivers to the hearer or addressee are sometimes ambiguous, ambiguous is a sentence that has more than one normal interpretation as incorrect sentence structure, imprecise intonation and use of polysemic words. In fact, the hearer or addressee tends to encounter difficulties in understanding what the speaker intends to say when they speak English. This situation can become a problem in communication. Context is condition where an event happens. Without context, the addressee would find problems to fully comprehend what the speaker suggests. 
One of the biggest problems in communication that could happen to the speaker and hearer is when both parties experience miscommunication about the meaning of the words that are related to the context of the situation. If the hearer knows the context, the language used by the speaker can be clearly understood.

The study of contextual meaning is called pragmatics. In studying pragmatics, we learn the ways to recognize the utterance of the speaker in the spoken and written form. According to Levinson (1983:8), pragmatics is the study of the relations between language and context that are grammaticalized or encoded in the structure of a language [1].

There have been a number of writers discussed deixis. Among them are as follows. Samosir (2012) talked about deixis in the Jakarta Post, she focused on the type of deixis and find out the most dominant type of deixis in the political article of Jakarta Post [2]. Pasaribu (2010) explained deixis used on business brochures text, she focused on the analysis of discourse deixis by using the percentage formula [3]. Furthermore Ekowati (2004) wrote about the use of pragmatic deixis in conversation texts in "pathway to English" [4], she focused on deixis analysis used in the text conversations and explained the way to use in the different context. Lastly, Wahyudi discussed pragmatics study on deixis in the Jakarta post editorial [5], he focused on the implementation of deixis in Jakarta post for July 2012 editorial.

This research possesses certain differences compared to the previous researches. the first difference is the object used in the research. The second difference is the focus of the research, this research focused on and elaborate deixis from its function, types and examples of each deixis in the drama. Meanwhile, the other researches only focused on certain kinds of deixis without explaining the functions of such deixis on the research.

Deixis could always be found in our daily conversation or in texts. According to Saeed (2003: 182) "Deixis is a technical term (form Geek) for one of the most basic things we do with utterance; it means 'pointing' via language" [6]. Whereas according to Yule (1996:9) "Any linguistic form used to accomplish this 'ponting' is called a deitic expression" [7]. Further Yule stated that deixis is clearly a form of referring that is tied to the speaker's context, with the most basic distinction between deitic expression being 'near speaker' and 'away from speaker'. In other words, deixis always needs the context to determine the referral. Traditionally, deictic consists of person or personal deixis, spatial or place deixis, and temporal or time deixis. Levinson also stated that (1983:54), there are five categories of deixis, namely the person deixis, time deixis, place deixis, social deixis, and discourse deixis [8]. The person deixis consists of three parts. First person deixis (I) and the second person deixis (you), and the third person deixis (he,she,or it). The spatial or place deixis consist of words related to the location such as in Makassar, at school, in Market and etc of the speech event. It contains demonstrative pronouns such as this and that and the demonstrative of adverb of place such as here and there. For the time or temporal deixis, it concerns the time of speech event. It includes words such as now, then, yesterday, tomorrow, today, tonight, next week, last week, and this week. The categories can be used to analyze the language uttered by the speaker that sometimes the hearer or addressee do not understand. Hence, deixis by understanding well students feel easier to understand.

Deixis is found not only in everyday language, but also in literature, for example the drama. The drama is a work of art that has been worldwide literary and theatrical shows, the arrangement of the stage, music, natural beauty and most importantly the use of light and color.

Sometimes the readers find difficulties to understand the meaning of the words in drama easily if they know about the context. In this study, the writer focused her research on deixis in "The 12 Angry Men" drama by Reginald Rose, because the plot of the story occurs in daily life, and drama script is one of the appropriate objects for analyzing dexis because the sentences in the drama script belong to spoken language.

Based on the explanation above, the writer would like to write deixis. Entitled AN ANALYSIS OF DEIXIS IN "THE 12 ANGRY MEN"DRAMA SCRIPT BY REGINALD ROSE.

\section{Identification of Problem}

Based on the background of research which has been previously mentioned, the writer find some problem occurs in "The 12 Angry Men", such as :

\section{A deictic problem occurs when the speaker or the hearer say ambiguous words to each other. Lack of knowledge of the readers about the importance of use is deixis in daily life. Scope of Problem}

Based on the identification of problem, the writer takes the problem of deixis as the main target of this research. To easily understand the explanation, the researcher limits the scope of this study in order to make it more detailed and focused. This study is limited to the analysis of deixis only, which can be found in the drama "The 12 Angry Men" by Reginald Rose.

\section{Research Question}

Based on the focus of the research, some questions can be formulated in this research 
What are the types of deixis found in "The 12 Angry Men" drama script by Reginald Rose?

1.4.2 What are the functions of each deixis types found in "The 12 Angry Men" drama script by Reginald Rose? Objectives of Writing

Based on the research questions above, the purpose of this research are as follows:

To disclose the types of deixis in "The 12 Angry Men" drama script by Reginald Rose To reveal the functions of each deixis types in "The 12 Angry Men" drama script by Reginald Rose

Significance of The Research

The findings of this research are expected to give contributions to people, especially to English learners and readers.

\section{English teachers}

The findings are expected to give information about deixis in the drama The 12 Angry Men, so that English teachers can teach it to their students in analyzing literary works. So, English teachers not only concern grammatically form in teaching English, but also concerning in the context.

\section{English learners as foreign language learners}

This research can enrich English learner's knowledge about deixis types and in conversation actually by using drama as the media.

\section{The readers}

In relation to the field of literature, this research is expected to increase the readers' knowledge about deixis. The readers can learn another way to understand the meaning of the drama's context through its actual written form. With this, readers can understand more about the story conveyed through the drama.

\section{Theoretical Reviews}

\section{The Theory of Pragmatics}

NPragmatics is one branch of linguistics, which studies language. Pragmatics focuses on conversational implicature, which is a process in which the speaker implies and the listener infers. In a sense, pragmatics is seen as an understanding between people to obey certain rules of interaction. In everyday language, the meaning of words and phrases are constantly implied and not explicitly stated. In certain situation, words can have a certain meaning. One might think that words always have a specifically defined meaning, but that is not always the case. Pragmatics studies how words can be interpreted in different ways based on the situation.

Yule (1996:3) "states that Pragmatics is studies about the speaker meaning, contextual meaning, it studies about how more gets communicated that said as well as the expression of relative distance" [9]. Levinson (1983:21) "states that pragmatics is the study of relations between language and context that are basic to an account of language understanding" [10].

\section{Drama 9}

Drama is a specific mode represented through performance. The term comes from a Greek word meaning "action". In English (as was the analogous case in many other European languages), the word "play" or game" (translating the Anglo saxon plega or Latin ludus) was the standard term used to describe drama until William shakespeare's time, just as its creator was a "play maker" rather than a "dramatist" and the building was a "play house" rather than a "theatre". The use of "drama" is a narrower sense to designate a specific type of play date from modern era. "Drama" in this sense refers to a play that is neither a comedy nor a tragedy, for example, Zola's Therese Raquin(1873) or Chekhov's lvano(1887). It is these narrower sense that the film and television industries, along with film studies, adopted to describe "drama" as a genre within their respective media.

The enactment of drama in theater, performance by actors on a stage before an audience, presupposes collaborative modes of production and a collective form of reception. Drama is often combined with music and dance -the drama in opera is generally sung throughout; musicals generally include both spoken dialogue and songs; and some forms of drama have incidental music or musical accompaniment underscoring the dialogue. 
Deixis

Deictic expressions are also sometimes called indexical. Deixis form is always tied to the speaker's context. From the definitions above, the researcher concludes that deixis are words that refers to things that always move or change depending on the analysis of context of the speaker, place, and time.

In my opinion, words like I, here, and now are deixis words. These kind of words do not have a fix referent. They are different with words like chair, house, and paper. Anyone who says chair, house, and paper, in whatever and whenever, the referents are still the same. But, referent in the words I, here, and now, the referent can be known by knowing when, where, and who the words are being spoken.

\section{Function of Deixis}

According to Yule's theory, the deixis functions as a 'pointer'. Pointing here refers to pointing thing or person, commonly known as person deixis. A person deixis functions as a reference to things or person in the speaker's utterance. Person deixis is divided into three parts, namely the first person deixis, second person deixis, and third person deixis. The first person deixis refers to himself, as the speaker who delivers the message. The second person deixis refers to the addressee as the listener, in other words, the person who receives the message. Where as the third person deixis refers to other people who is neither the speaker nor the addressee. Spatial deixis refers to pointers of the location of the speaker. It could either be in a proximal form which is close from the speaker, or a distal form which is far away from the speaker. Lastly, temporal deixis particularly refers to the spoken time of the utterance.

\section{The 12 Angry Man Drama}

The 12 Angry Men is a 1957 American noir courtroom drama film adapted from a teleplay of the same name by Reginald rose. Written and co-produced by Rose himself and directed by Sidney Lumet, this trial film tells the story of a jury made up to 12 men as they deliberate the guilt or acquittal of a defendant on the basis of reasonable doubt. In the United States, a verdict in most criminal trials by jury must be unanimous.

\section{Methodology}

\section{Research Method}

The writer used a descriptive qualitative method. This method described the data and rich understanding about deixis on each drama script conversation. The writer collected, identified and analyzed the data through systematic steps using qualitative way.

\section{Data and Source}

The data of this research were taken from Reginald Rose's drama script which were taken from her drama "The 12 Angry Men" [11], included 12 juror's conversations

\section{Findings and Discussion}

\section{Types of Deixis in Drama Script of Reginald Rose's The 12 Angry Men}

\section{Personal Deixis}

Personal deixis concerns the encoding of the role of participants in the speech event in which the utterance in the question delivered, (Levinson 1983:65). There are three types of personal deixis can be found on the script. It can be seen in this table 4.1:

From the table above, it can be seen that in 12 jurors from The 12 Angry Men, personal deixis and the three types of personal deixis are occur. First juror is "juror 1" in the drama "juror 1" which is consisting of one of his conversation, the writer finds the use personal deixis in every conversation.

Second is "Juror 2". This juror consists of four conversations and in every conversation, personal deixis always occurs. Personal deixis that occurs in this drama is completed and followed by the three types of personal deixis.

Third is "Juror 3". This juror consists of seven conversations. The use of personal deixis in this drama is to indicate the use of personal pronoun in the drama script. Personal deixis that occurs in this drama is complete and followed by the three types of personal deixis.

Fourth is "Juror 4". This juror consists of three conversations. This conversation uses personal deixis to indicate the use of personal pronoun. The writer finds five words that include personal deixis which is include two words as first person deixis, one word as second person deixis and two words as third person deixis. 
Table 1. Personal Deixis Used by 12 Jurors

\begin{tabular}{lllll}
\hline & & \multicolumn{3}{c}{ Personal Deixis } \\
\cline { 3 - 5 } No & Juror & First person & Second person & Third person \\
\hline 1 & Juror 1 & I, my & You, your & It, they \\
2 & Juror 2 & I, we & You & It \\
3 & Juror 3 & I & You & She, her, it \\
4 & Juror 4 & I, my & You & They,them \\
5 & Juror 5 & I & You,your & He, it \\
6 & Juror 6 & I, we & Your & It, they \\
7 & Juror 7 & I, my, we & You, your, your- & He, his, it, them \\
& & & self & \\
8 & Juror 8 & I, we, our & You & They \\
9 & Juror 9 & I, we & You & They \\
10 & Juror 10 & I, my & You & It \\
11 & Juror 11 & I, we & You & It \\
12 & Juror 12 & I, my & You & She, it \\
\hline
\end{tabular}

Fifth is "Juror 5". This drama consists of three conversations. This conversation uses personal deixis to indicate the use of personal pronoun.

Sixth is "Juror 6". This drama consists of five conversations. This conversation uses personal deixis to indicate the use of personal pronoun. The writer finds five that include personal deixis consists of two word as first person deixis, one word as second person deixis and two word as third person deixis.

Seventh is "Juror 7". This juror consists of eight conversation and in every conversation, personal deixis always uses. The writer finds ten words that include personal deixis, four words as first person deixis, two word as second person deixis and four words as third person deixis.

Eight is "Juror 8". This juror consist of six conversation. The writer finds the use of personal deixis in every conversation of this drama include first and second person deixis.

Ninth is "Juror 9". This drama consists of three conversation. This conversation use personal deixis to indicate the use of personal pronoun. The writer finds five words that include personal deixis consists of three word as first person deixis, one word as second person deixis, and one word as third person deixis.

Ten is "Juror 10". This drama consists of seven conversation. This conversation use personal deixis to indicate the use of personal pronoun. The writer finds four words that include personal deixis consists of two words as first person deixis, one word as second person deixis, and one word as third person deixis.

Eleven is "Juror 11". This drama consists of four conversation. This conversation use personal deixis to indicate the use of personal pronoun. The writer finds four words that include personal deixis consists of two words as first person deixis, one word as second person deixis, and one word as third person deixis.

12 is "Juror 12". This drama consists of seven conversations. This conversation use personal deixis to indicate the use of personal pronoun. The writer finds six words that include personal deixis consists of two word as first person deixis, two word as second person deixis, and two word as third person deixis.

From all explanation above, the writer concludes that from drama script in The 12 Angry Men, the use of personal deixis and followed by the three types of deixis are occur. The function of personal deixis is to indicate the use of personal pronoun in the drama script.

\section{Spatial Deixis or Place Deixis}

Spatial deixis or place deixis concerns the encoding of spatial location relative to the location of participant in the speech event, Levinson (1985: 62). From juror's conversation in The 12 Angry Men, the writer finds and classifies the 12 data or 12 juror which are show the spatial or place deixis.

From 12 jurors in drama script, spatial or place deixis is used in four jurors. Four of them are "juror 1, juror 7, juror 8 , juror 10 ". The occurring of spatial deixis or place deixis in the "juror 1 "is represented by use of word "here". While, in the "juror 7", the writer finds two words that indicate spatial or place deixis, include the use of word "here and home". "juror 8" is represented by use of word "here". The last is in the "juror 10". The writer finds two words as spatial deixis that is the use of word "there and here".

From explanation above, the writer can concludes that not all the drama script in the 12 angry men uses spatial or place deixis in the drama script. It means that the writer of drama script does not mention the location of the event in the drama script happen.

\section{Temporal or Time Deixis}

Temporal or time deixis concerns the encoding of temporal points and spans relative to the time at which an utterance was spoken (or written message inscribed), Levinson (1985:62). It means that time deixis is references that it is used 
to state the time when the utterance is uttered. From the drama in The 12 Angry Men, the writer finds and classifies the 12 data from the juror which are show temporal or time deixis.

From 12 juror in the 12 angry men, "juror 1" is use a temporal or time deixis "now and midnight" to indicate it. This word occurs only in the four conversations. Next is "juror 2" the writer found one temporal deixis including word "last night". The word last night just in second conversation. In "juror 3" the writer finds two that include temporal deixis they are "the night and a day". And in "juror 7 " the writer finds one that include temporal deixis is "now". Next is "juror 8" the writer finds two that include temporal deixis they are "five minutes and eight o'clock". In this "juror 10" the writer only finds one temporal deixis represented by use of word "three days". And the last is "juror 12" the writer only find one temporal deixis represented by use of word "now". And in juror 4, 5, 6, 9 and 11 the writer does not find a temporal deixis.

From explanation above, the writer concludes that temporal or time deixis mostly use in the drama script. The use of temporal deixis indicates the time when the even in the drama script happen.

\section{Social Daixis}

Social deixis is connected with the social distinction with participant who has role, (Levinson, 1983:89). There are two basic kinds of social deixis information that seems to be encoded in language around the world, include relational social deixis and absolute social deixis. The writer uses table to gives information about 12 jurors in The 12 Angry Men which is use social deixis in the drama script.

Table 2. Social Deixis Used by 12 Jurors

\begin{tabular}{cll}
\hline & \multicolumn{2}{c}{ Personal Deixis } \\
\cline { 2 - 3 } Juror & Relational Social Deixis & Absolute Social Deixis \\
\hline 1. & - & - \\
2. & - & - \\
3. & - & Women, father, and kid \\
4. & - & Boy, father \\
5. & - & - \\
6. & - & Wife \\
7. & - & Boy \\
8. & - & Boy \\
9. & - & Women \\
10. & Bastard & - \\
11. & - & Man \\
12. & - & - \\
\hline
\end{tabular}

From the table above, it can be seen that from 12 jurors in The 12 Angry Men, only seven juror which use social deixis in their drama script is. There are two kinds of social deixis, include relational social deixis and absolute social deixis. Relational social deixis is deictic reference to a social relationship between the speaker and addresser. While absolute social deixis is a deictic reference usually express in certain forms of address.

First is "juror 3" this script used three words as the social deixis which is represents by use of words "women, father and kid". Then in "Juror 4" the writer finds also there are two words as the social deixis shows by use of words "Boy, and Father". Next is "Juror 6" which is use one word indicates social deixis that is use of word "wife". And in "juror 7" which is use one word indicates social deixis that is use of word "boy". For "juror 8" which is use one word as the social deixis is represented by use of word "boy". Next is "Juror 9" which is use one word indicates social deixis that is use of word "women ". Then in "Juror 10" the writer find also there is one word as the social deixis show by use of word "Bastard". The last is "Juror 11" the writer find there is one word as the social deixis shows by use of word "Man".

\section{Conclusion}

Types of deixis found in the drama script of The 12 Angry Men by Reginald Rose are Personal Deixis, Temporal Deixis, Spatial Deixis and Social Deixis. The function of each deixis found in the drama script of The 12 Angry Men by Reginald Rose are personal deixis which refers to role of participant and addressee in the drama, Temporal deixis gives the information about the moment of the utterance in context that is happened, Spatial deixis is to know the distance about the speech situation between the participants happened, and the last is social deixis to show the social status of the person included relational social or absolute social deixis. Furthermore, the use of first singular person deixis like "I, me, myself" always refers to the writer because the writer as main subject in every drama script. While for first plural person deixis like "we, our" mostly refer to the writer and the reader. Then second person deixis "you, your, yourself" mostly refer to the reader because the writer invites the reader to imagine they take 
role in the context. Then for pronoun "she, her" is belonging to the girl as the writer participant. The plural "they, them" mostly refer to the addressee in the context. The third pronoun "it" is referred to things that has already been mentioned earlier. Temporal deixis is generally expressed in the whole time, such as today, every day, now, lastnight, three days and etc. which are refer to the relative time in that context. Place deixis is generally happened in "here, there, this, anywhere" which is refer to the location where the writer or addressee take place in the drama.

\section{References}

[1] Levinson, Stephen C. Pragmatics. New York: Cambridge University Press, 1983

[2] Samosir. Deixis in the Jakarta post. Indonesia, 2012

[3] Pasaribu. Deixis used on business brochures text. Indonesia, 2010

[4] Ekowati. The Use of Pragmatic Deixis in Conversation Text in Pathway to English, Indonesia 2004

[5] Wahyudi. Implementation of Deixis in Jakarta Post, 2001

[6] Saeed. Linguistics in the Centre for Language and Communication Studies. Irlandia: University of Dublin, 2003

[7] Yule, George. Pragmatics. New York: Cambridge University Press, 1996

[8] Levinson, Stephen C. Pragmatics. New York: Cambridge University Press, 1983

[9] Brown, Gilian and Yule, George. Discourse analysis. New York : Cambridge University press, 1983

[10] Yule, George. The Study of Language, $2^{\text {nd }}$ ed. New York: Cambridge University Press, 1985

[11] Rose, Reginald. (1957). Drama Script [Online]. Available: www. scripts12angrymen .com 